DOI:

УДК 658.562.64:624.014:621.65

Ю.А. Гасило, к.Т.н., доцент

Р.Я. Романюк, к.т.н., доцент

Дніпровський державний технічний університет, м. Кам'янське

\title{
ІННОВАЦІЙНІ МЕТОДИ НЕРУЙНІВНОГО КОНТРОЛЮ ЯКОСТІ МЕТАЛОКОНСТРУКЦІЙ ТА ТЕХНОЛОГІЧНОГО УСТАТКУВАННЯ
}

Проаналізовано сучасні неруйнівні методи контролю якості металоконструкиій та технологічного устаткування з метою підвищення терміну їх роботи - методи контролю матрицями вихрострумових датчиків та вібращійної діагностики. Розглянуто принципи дії, переваги та недоліки даних методів.

Ключові слова: датчик; дефектоскоп; неруйнівний контроль; діагностика вібрацією; дефект.

Modern non-destructive methods quality control of metal structures and technological equipment are analyzed in order to increase their service life - methods control by matrices of eddy current sensors and vibration diagnostics. The principles of operation, advantages and disadvantages of these methods are considered.

Keywords: sensor; flaw detector; non-destructive testing; vibration diagnostics; defect.

\section{Постановка проблеми}

Неруйнівні методи контролю якості та випробування металів включають беззразкові випробування і дефектоскопію. Прийнято, що під терміном "неруйнівні фізичні методи контролю" розуміють види контролю, які мають дві характерні ознаки:

- вони не повинні призводити до руйнування (ушкодження) контрольованого об'єкта;

- вони засновані на взаємодії фізичних полів або речовин з дефектами.

В основу класифікації методів неруйнівного контролю покладено фізичний процес 3 моменту взаємодії фізичного поля або речовини з контрольованим об'єктом до одержання первинної інформації $[1,2]$.

Неруйнівний контроль (НК) поділяється на наступні види: візуально-вимірювальний, акустичний, магнітний, оптичний, капілярний, течіє шуканням, радіаційний, радіохвильовий, тепловий, електричний, електромагнітний вихрових струмів (вихрострумовий).

Жоден $з$ методів НК не $є$ універсальним, тому при технічному діагностуванні дуже важливий не тільки правильний вибір методу контролю, але і комбінування ряду методів, сполучення неруйнівних і руйнівних випробувань, а також проведення мікроскопічного дослідження тощо. Найважливішими характеристиками неруйнівних методів контролю $є$ їхня чутливість $\mathrm{i}$ роздільна здатність, простота і доступність технологічного процесу контролю, а також надійність апаратури.

\section{Аналіз останніх досліджень та публікацій}

Найважливіший показник надійності і довговічності металоконструкцій та обладнання - стан поверхневого шару конструкції та деталей устаткування, оскільки руйнування конструкційного матеріалу починається з його поверхні. Утворення різних дефектів на поверхні виробу внаслідок абразивного зношення, дії активних середовищ тощо призводить до втрати необхідних якісних характеристик металоконструкції та деталей устаткування. Усі дефекти викликають зміну однієї або декількох фізичних характеристик металів і їх сплавів - щільності, електропровідності, магнітної проникності, пружних властивостей тощо.

Використання методів поверхневого зміцнення конструкційних матеріалів дозволяє вирішити багато найважливіших технічних завдань, але при цьому у кожному конкретному випадку потрібний ретельний підхід при виборі способу зміцнення або нанесення захисних покриттів [3]. 
Крім цих способів існують також методи, які не пов'язані з відновлення поверхні матеріалів, а суть їх полягає у застосуванні сучасних неруйнівних методів контролю якості металоконструкції, зокрема у встановленні закономірностей між внутрішнім станом деталей устаткування та їх зношенням. Ці методи дозволяють оцінити загальний технічний стан обладнання, за необхідності провести поглиблений аналіз його технічного стану, визначити причини зростання досліджуваних параметрів, встановити дефекти і їх усунути, тобто підвищити надійність експлуатації металоконструкції, устаткування та збільшити термін їх роботи.

\section{Формулювання мети дослідження}

Метою даної роботи є аналіз сучасних неруйнівних методів контролю якості металоконструкцій та технологічного устаткування з метою підвищення терміну їх роботи.

\section{Виклад основного матеріалу}

Перша частина роботи присвячена одному з нових та перспективних напрямків у неруйнівному контролі металоконструкцій - контроль вихрострумовими матрицями.

Сучасний вихрострумовий дефектоскоп є компактним приладом з автономним живленням, оснащеним екраном, клавіатурою і датчиками з можливістю виведення необхідних параметрів на різні пристрої, включаючи персональний комп'ютер, принтер, карту пам'яті тощо. Сучасні багатофункціональні вихрові дефектоскопи здатні не тільки аналізувати контрольовані дільниці, але і обробляти інформацію з наданням розгорнутого технічного звіту як у лабораторних, так і в польових умовах.

Основу приладу складає виносний датчик (рис. $1, a$ ), який при протіканні крізь нього змінного струму створює вихрові струми у контрольованій області. Будь-які несуцільності або зміни властивостей матеріалів, які змінюють вихрові струми в контрольованій області, реєструються виносним датчиком і розглядаються як можливі дефекти. Сканування дефектів даним способом є зворотно-поступальним.

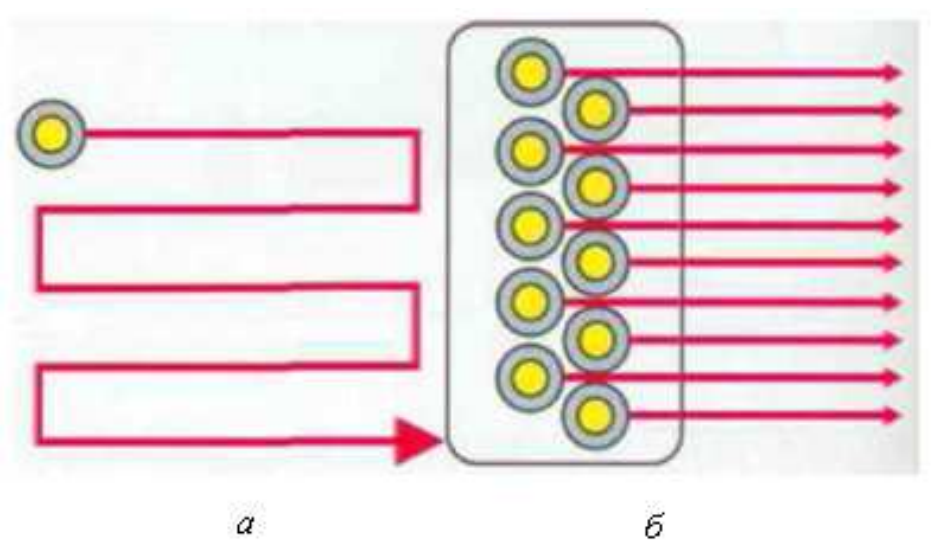

Puc. 1. Принцип дії вихрострумового дефектоскопа: $a-3$ використанням одного датчика (зворотно-поступальне сканування); $\sigma-3$ використанням матриці датчиків (лінійне сканування)

У теперішній час даний прилад істотно вдосконалений. У ньому використовується матриця вихрострумових датчиків (рис. 1, б).

Метод контролю з використанням матриці вихрострумових датчиків засновано на електронному управлінні і зчитуванні інформації з кількох вихрострумових датчиків, розташованих у вигляді матриці на об'єкті контролю (лінійне сканування). Збір даних став можливий завдяки використанню мультиплексора, що дозволяє усунути взаємний вплив між окремими датчиками. Замінити зворотно-поступальне сканування на сканування в одному напрямку дозволяе матричний вихрострумовий зонд.

Переваги методу контролю з використанням матриці вихрострумових датчиків у порівнянні з одноканальним вихрострумовим контролем полягають у наступному: 
- істотно скорочується час проведення контролю;

- охоплюється більша площа за один прохід;

- спрощується конструкція механічних і автоматизованих систем сканування;

- результати контролю заданої області надаються у режимі реального часу;

- спрощується інтерпретація даних;

- підвищується надійність і достовірність контролю.

Матриця вихрострумових датчиків може бути оптимізована для кожного конкретного випадку шляхом зміни взаємного розташування окремих датчиків і форми всієї матриці. Більші перспективи відкриває застосування у вихрострумових системах комп'ютерної техніки, що забезпечує як автоматичне керування усім циклом виміру, так і інтерпретацію отриманих результатів.

У системі, розробленою фірмою Oak Ridge, значною мірою реалізовані ці можливості. Система контролю металевих кожухів надпровідних магнітів, призначена для цехових умов, проводить аналіз одночасно на трьох частотах, що дозволяє відразу визначати положення і розміри дефектів, а також робити відбудовування від “зазорів” [1].

Однією з компаній, яка займається виробництвом матричних датчиків широкої області застосування, є Olympus NTD Inc [4]. Ці датчики можуть бути сконструйовані для виявлення заданого типу дефектів або для обстеження контрольованої деталі заданої форми. Стандартні матриці виконуються для реєстрації поверхневих і підповерхневих дефектів.

Виведення результатів відіграє головну роль при використанні вихрострумових датчиків. Найпоширенішим способом є зображення у вигляді C-Скану (2D або 3D), що являє собою кодоване кольором дво- або тривимірне зображення контрольованої поверхні. Матриця датчиків рухається над дефектом, кожний датчик видає вихрострумовий сигнал. Вісь $\mathrm{X}$ відповідає напрямку руху матриці, а вісь Y - вісі зонда. Таким чином, С-Скан надає інформацію як про положення дефекту, так і про його розміри, що підвищує надійність контролю, оскільки здійснюється повне охоплення поверхні контролю.

Іншою компанією, яка випускає сучасні дефектоскопи (Reddy) з технологією вихрострумових матриць, $\epsilon$ Eddyfi [5].

Reddy підтримує усі матричні перетворювачі виробництва компанії Eddyfi, у тому числі перетворювачі серії I-Flex, призначені для контролю об'єктів складної форми. Матриця підбудовується під геометрію контрольованої поверхні і повністю повторює ії форму. Залежно від моделі перетворювача застосовуються циліндричні котушки діаметром від 2 до 6 мм, що забезпечує високу роздільну здатність. Серійно випускаються перетворювачі з кількістю котушок від 16 до 128. Глибина проникнення вихрових струмів у сталь становить до 5 мм.

Найбільш розповсюдженим застосуванням вихрострумового контролю 3 матричними перетворювачами $є$ пошук і картографування стрес-корозійних уражень у металі. Розвиток даного типу дефектів вкрай важко виявляється традиційними методами, однак саме вони $є$ причиною численних аварій на магістральних газопроводах в усьому світі. Статистика свідчить, що у випадку несвоєчасного виявлення (або пропуску) осередку стрес-корозії, що розвивається, враховуючи стабільно високий тиск у магістральній газовій трубі, даний дефект безсумнівно призведе до пориву і “розкриття” трубопроводу на даній дільниці.

Далі розглянемо перетворювачі, розроблені спеціально для контролю високовуглецевих сталевих металоконструкцій. Матриця у них містить не тільки традиційні вихрострумові котушки, але і тангенціальні (ТЕСА). Вісь обмотки тангенціальних котушок розташовується паралельно скануючій поверхні. Тангенціальні котушки генерують вихрострумовий потік, що протікає паралельно поверхні. Дуже висока проникаюча здатність дозволяє ефективніше вимірювати глибину залягання великих тріщин.

Серія перетворювачів з технологією ТЕСА є запатентованою розробкою компанії Eddyfi i називається Schark. Вони виконані таким чином, щоб можна було контролювати валик шва будь-якої висоти. Кожний підпружинений елемент у перетворювачі складається з трьох котушок: дві з них тангенціальні (збуджуюча, приймаюча), третя — традиційна котушка для виявлення тріщин, поперечних вісі сканування. 
Комплексна робота усіх котушок, які створюють у матриці єдиний масив 3 кількох десятків елементів, дозволяє генерувати вихрові струми 3 можливістю проникнення на глибину до 10 мм. Сканування можна проводити зі швидкістю до 200 мм/с.

Дані контролю збираються і перетворюються за допомогою програмного забезпечення Magnifi GO в інтуїтивно зрозумілі цифрові C-Скани, що полегшують аналіз результатів, у який зокрема входять виміри глибини і довжини дефектів (рис. 2).

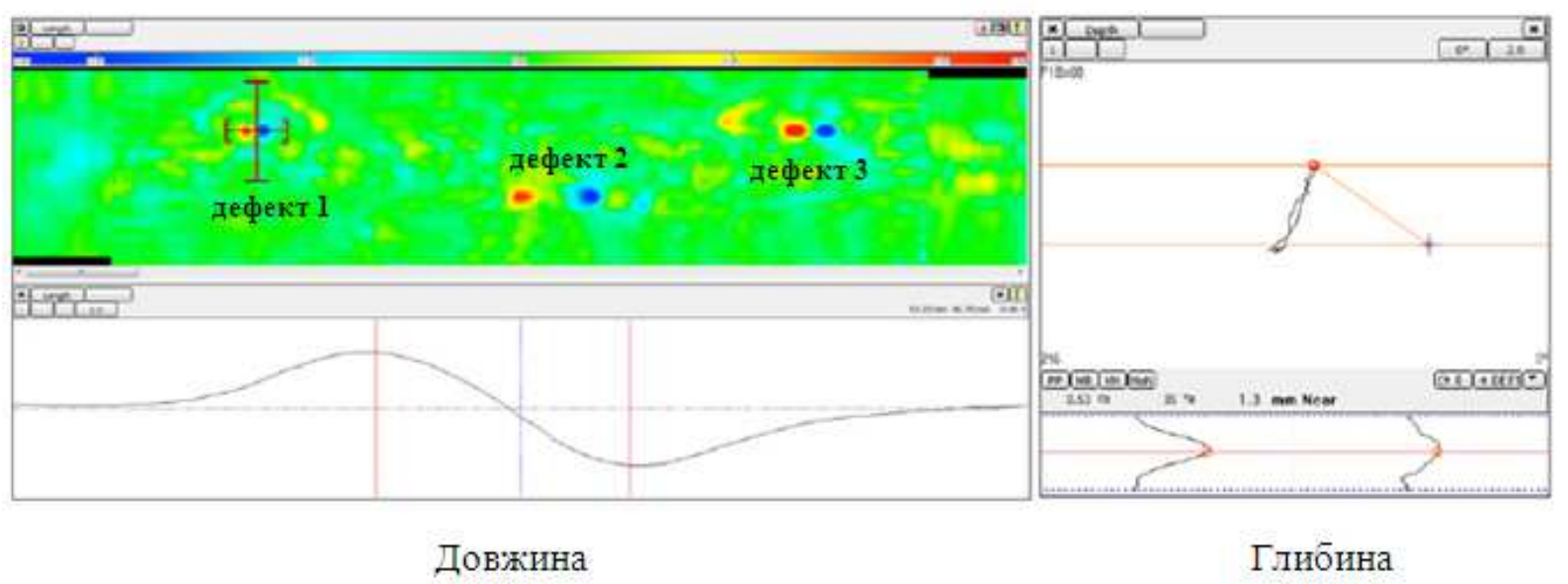

Puc. 2. C-Скан (2D) результатів вимірювання розмірів дефектів приладом Reddy 3 перетворювачами Schark

Отже, технологія вихрострумових матриць у значній мірі дозволяє полегшити процес контролю, гарантує високу швидкість, достовірність і якість отриманих результатів.

В наступній частині роботи розглянемо інший інноваційний метод неруйнівного контролю якості деталей обладнання - метод вібраційної діагностики. Він застосовується для прогнозування залишкового ресурсу роботи устаткування, наприклад, грунтових насосів.

Діагностика устаткування за вібрацією, що збуджується у ньому, — найбільш ефективний спосіб попередження серйозних інцидентів, оскільки більш ніж у 80 \% випадків появи незворотних змін стану окремих вузлів змінюються різні параметри вібрації машини. Навіть при стрибкоподібній зміні стану окремих вузлів періодичний контроль вібрації дозволяє виявити незворотні зміни стану до того, як виникне відмова даної машини або обладнання $[6,7]$.

Вібрація насосних агрегатів істотно зростає зі збільшенням гідроабразивного зношування. Для встановлення залежності часу напрацювання насосних агрегатів від гідроабразивного зношування необхідно на кожному насосі встановити вібродатчики, що передають інформацію про роботу насоса на загальний пульт машиніста насосної станції.

При дослідженні частотного спектра можна виявити складові, що відносяться безпосередньо до певних збудливих сил. Майже усі спектри механічних коливань мають також важливі складові з частотами, пов'язаними з рухами окремих вузлів і деталей машин. Утворення і розвиток дефекту призводить до появи у спектрі таких складових амплітуди, які зростають у міру зміни параметрів дефекту. Частоти, на яких спостерігаються ці складові, можуть бути заздалегідь розраховані за конструктивними параметрами об'єкта діагностування і за частотою обертання. Отже, при діагностуванні наявність дефектів може бути виявлена на ідентифікаційних частотах.

Об'єктом діагностування за цим методом є підшипники кочення. Ідентифікаційні частоти визначаються частотою перекочування тіл кочення по зовнішньому кільцю. У якості параметрів вимірювання найчастіше використовуються вібропереміщення, віброшвидкість та віброприскорення.

Поява на частотному спектрі піка у певній частотній смузі з супергармоніками (кратні гармоніці) свідчить про наявність конкретного виду дефекту. Якщо на спектрограмі підшипни- 
ка кочення пікова смуга збігається з частотою обертання вала насоса, то це може бути пов'язане 3 його дефектом (неврівноваженість), дефектом з'єднувальної муфти, вигином вала тощо. Якщо пік зі своїми гармонійними складовими збігається з більшістю частотних значень елементів підшипника, то це означає, що починається наддопустиме коливання, при якому необхідно зупинити насос.

Для прикладу на рис. 3 наведені результати вимірювання вібрації насоса на опорних підшипниках вала за допомогою вібродатчиків, які встановлені на корпусах переднього і заднього підшипників. Виміри проводилися через кожні 300 год.

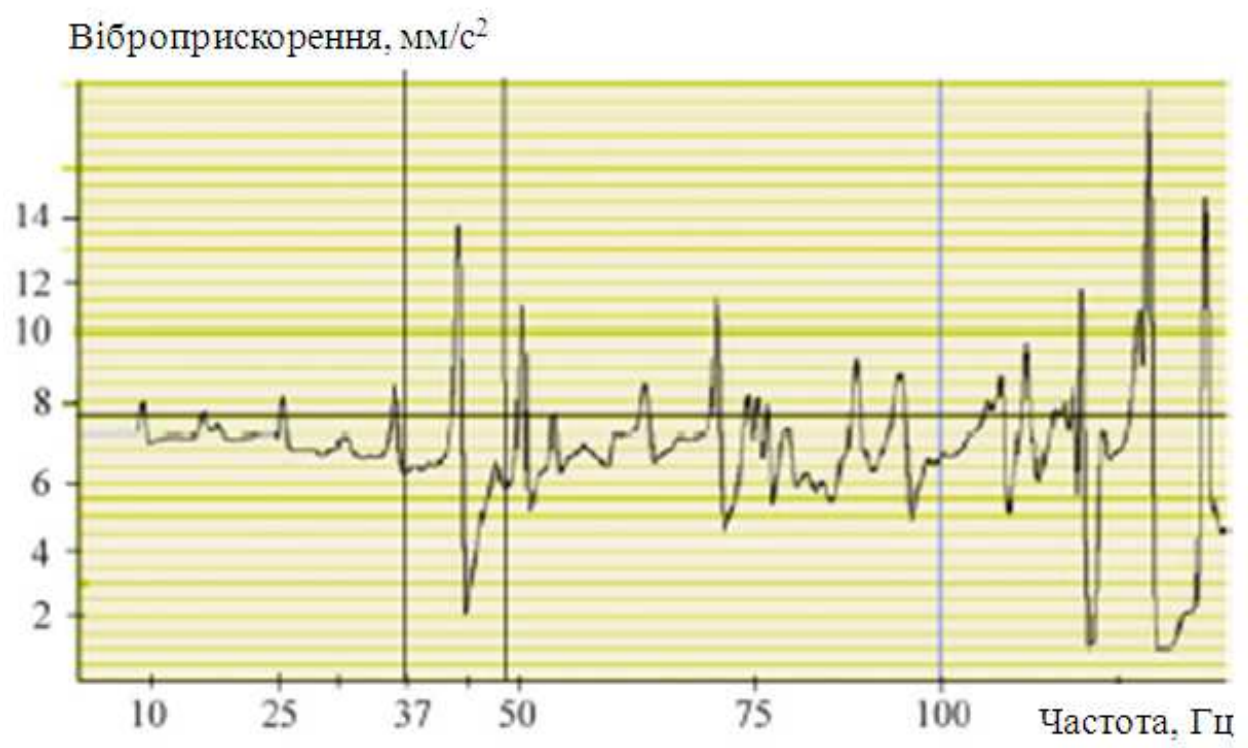

Puc. 3. Діаграма діагностування стану грунтового насосу за допомогою вібродатчиків

На цьому рисунку можна побачити стрибок віброприскорення при експлуатації насоса протягом 30 діб. Це свідчить про те, що відбулося граничне зношування робочого колеса та елементи підшипника випробовують граничні вібрації, які неминуче призведуть до його поломки.

Отже, за допомогою даного методу можна спрогнозувати термін поломки устаткування і запланувати його технічне обслуговування та ремонт.

\section{Висновки}

Проаналізовано інноваційні неруйнівні методи контролю якості металоконструкцій та технологічного устаткування - методи контролю матрицями вихрострумових датчиків та вібраційної діагностики.

Переваги контролю вихрострумовими матрицями полягають у наступному: істотно скорочується час проведення контролю, охоплюється більша площа за один прохід, спрощується конструкція механічних і автоматизованих систем сканування, результати контролю заданої області надаються у режимі реального часу, спрощується інтерпретація даних, підвищується надійність і достовірність контролю.

Діагностика устаткування за вібрацією відноситься до ефективного способу попередження серйозних інцидентів, оскільки появи незворотних змін стану окремих вузлів змінюють різні параметри вібрації машини. Це дозволяє виявити незворотні зміни стану до того, як виникне відмова даного механізму або обладнання. 


\title{
Список використаної літератури
}

1. Смирнов А. Н. Неразрушающие и разрушающие испытания сварных соединений : уч. пособ. Кемерово : ГУ КузГТУ, 2009. 187 с.

2. Камель Г. І., Гасило Ю. А., Івченко П. С., Романюк Р. Я. Контроль якості зварювання. Т. 1. Неруйнівні методи контролю : навч. посіб. Кам’янське : ДДТУ, 2018. 240 с.

3. Гасило Ю. А., Романюк Р. Я., Крюковська О. А. Особливості контролю якості зварних конструкцій з використанням матриці вихрострумових датчиків. Збірник наукових праць Дніпровського держсавного технічного університету (технічні науки). Кам'янське : ДДТУ, 2019. Випуск 1(34). С. 50-54.

4. NDT Systems : вебсайт. URL: https://www.ndtsystems.com (дата звернення 12.09.2020).

5. Eddyfi Technologies : вебсайт. URL: https://www.eddyfi.com/en (дата звернення 12.09.2020).

6. Брусова О. М. К вопросу повышения срока службы грунтовых насосов. Вестник ПНИПУ. Геология. Нефтегазовое и горное дело. 2014. № 10. С. 98-106.

7. Гасило Ю. А., Романюк Р. Я., Крюковська О. А. Аналіз методів збільшення ресурсу роботи грунтових насосів. Збірник наукових пращьь Дніпровського державного технічного університету (технічні науки). Кам'янське : ДДТУ, 2019. Випуск 2(35). С. 42-47.

\section{INNOVATIVE METHODS OF NON-DESTRUCTIVE CONTROL THE QUALITY METAL STRUCTURES AND TECHNOLOGICAL EQUIPMENT Hasylo Yu., Romaniuk R.}

\begin{abstract}
The most important indicator of the reliability and durability of metal structures and equipment is the condition of the surface layer of the structure and equipment parts, since the destruction of a structural material begins from its surface. The formation of various defects on the surface of the product due to abrasive wear, the action of active media, etc. leads to the loss of the necessary quality characteristics of metal structures and equipment parts.

The purpose of this work is to analyze modern non-destructive methods of quality control of metal structures and technological equipment in order to increase their service life.

This paper discusses innovative methods of non-destructive testing - methods of control by matrices of eddy current sensors and vibration diagnostics.

The control method using a matrix of eddy-current sensors is based on electronic control and reading information from several eddy-current sensors located in the form of a matrix on the controlled object (linear scanning). Data collection was made possible by the use of a multiplexer, which eliminates the mutual influence between individual sensors. The advantages of the inspection method using an eddy-current sensor array are as follows: the inspection time is significantly reduced, a large area is covered in one pass, the design of mechanical and automated scanning systems is simplified, the results of the control a given area are provided in real time, data interpretation is simplified, reliability is increased and reliability of control.

Diagnostics of equipment using vibration that is excited in it is the most effective way to prevent serious incidents, since in more than $80 \%$ of cases of irreversible changes in the state of individual units, various parameters of the machine vibration change. Even with an abrupt change in the state of individual units, periodic monitoring of vibration makes it possible to identify irreversible changes in state before a failure of this machine or equipment occurs.
\end{abstract}

\section{References}

[1] Smirnov, A.N. (2009). Nerazrushajushhie i razrushajushhie ispytanija svarnyh soedinenij [Nondestructive and destructive testing of welded joints]. Kemerovo: GU KuzGTU [In Russian]. 
[2] Kamel, H.I., Hasylo, Yu.A., Ivchenko, P.S., \& Romaniuk, R.Ya. (2018). Kontrol yakosti zvariuvannia. Neruinivni metody kontroliu [Welding quality control. Non-destructive methods of control]. Kamianske: DDTU [In Ukrainian].

[3] Hasylo, Yu.A., Romaniuk, R.Ya., \& Kriukovska, O.A. (2019). Osoblyvosti kontroliu yakosti zvarnykh konstruktsii z vykorystanniam matrytsi vykhrostrumovykh datchykiv [Features of quality control of welded structures using a matrix of eddy current sensors]. Zbirnyk naukovykh prats Dniprovskoho derzhavnoho tekhnichnoho universytetu (tekhnichni nauky) - Collection of cholarly papers of Dniprovsk State Technical University (Technical Sciences), 1(34), 50-54 (In Ukrainian).

[4] NDT Systems. Retrieved from https://www.ndtsystems.com.

[5] Eddyfi Technologies. Retrieved from https://www.eddyfi.com/en.

[6] Brusova, O.M. (2014). K voprosu povyshenija sroka sluzhby gruntovyh nasosov [On the issue of increasing the service life of dredge pumps]. Vestnik PNIPU. Geologija. Neftegazovoe i gornoe delo - PNRPU Bulletin. Geology. Oil and gas and mining, 10, 98-106 [In Russian].

[7] Hasylo, Yu.A., Romaniuk, R.Ya., \& Kriukovska, O.A. (2019). Analiz metodiv zbilshennia resursu roboty gruntovykh nasosiv [Analysis of methods to increase the service life of ground pumps]. Zbirnyk naukovykh prats Dniprovskoho derzhavnoho tekhnichnoho universytetu (tekhnichni nauky) - Collection of cholarly papers of Dniprovsk State Technical University (Technical Sciences), 2(35), 42-47. (In Ukrainian). 